\title{
MARKETING ANALYSIS OF THE DRUGS USED FOR THE TREATMENT OF AFFECTED MILITARY MEN WITH BRAIN INJURIES
}

\author{
O.P.Shmatenko, A.M.Solomenny, O.V.Pleshkova \\ Ukrainian Military Medical Academy
}

Key words: marketing analysis; brain injury; drug therapy; medicines

\begin{abstract}
During the research the comparative analysis of protocols of medical care for patients with brain injuries and information of scientific literature and evidence-based medicine has been conducted. It has demonstrated that for the treatment of affected military men with brain injury the following groups of drugs are used: antibacterial agents for systemic use, psychoanaleptics, blood substitutes and perfusion solutions, antiepileptics, vitamins, peripheral vasodilators, cardiac drugs, calcium channel blockers, analgesics, antihemorrhagic drugs, drugs for treating wounds and ulcers, diuretics, antithrombotic agents, antiparkinsonian drugs, psycholeptics, vasoprotectives, beta adrenoreceptor antagonists, etc. Marketing analysis of certain groups of drugs has been conducted according to the following criteria: legal (registration in Ukraine), economic (commercial: country, company), pharmaceutical (types of dosage forms, the composition of active substances, method of application), pharmacotherapeutic (ATC-classification). The analysis of the domestic pharmaceutical market has shown that drugs for treatment of head injuries comprise 1034 drugs manufactured in 39 countries. It has been found that the Ukrainian producers are able to provide the necessary level of rendering medical care in treatment of the traumatic brain injury, they produce 549 names of drugs, and it is almost $53 \%$ of the total range of medicines. The first place among the Ukrainian companies manufacturing drugs for treatment of the brain injury has "Darnitsa pharmaceutical company" JSC, the second one"Yuria-Farm" Ltd., the third place - Pharmaceutical company "Zdorovye" Ltd. Foreign producers supply 485 drugs (47\%). The leaders are India, Germany and Slovenia, which take the first, second and third places in the import of drugs, respectively.
\end{abstract}

Modern principles of qualitative medical care are associated with unification and standardization of the medical technologies, and it fully regards to drug provision of affected military men with with brain injuries. The introduction of standardized schemes of diagnosis and treatment in traumatic brain injury helps to reduce the fatality rate from 38 to $23 \%[6,9,14,17]$. At present recommendations only for sections of hyperventilation and anticonvulsant therapy have been formulated at the level of standards, but other effective methods of pharmacotherapy of patients with brain injuries directed to correction of homeostasis, stabilization of the function of cell membranes of neurons and glial cells, reduction of the harmful effects of hypoxia on the structure of the brain, stimulation of redox processes, intensification of oxygen and glucose utilization are fixed at the level of options $[7,10,12,16,17]$. There is also no research concerning generalization and systematization of the information about medicines used for drug therapy of military men with brain injuries. Therefore, development and introduction of formulary lists of drugs for treating the traumatic brain injury is relevant.

\section{Materials and Methods}

During analysis the research materials were data of protocols of medical care for patients with brain injuries, information of scientific literature and evidencebased medicine [1]. For analysis of groups of drugs the system-overview and marketing methods have been used. When conducting marketing analysis the following groups of parameters were used: 1) legal (registration in Ukraine), 2) economic (commercial: country, company), 3) pharmaceutical (types of dosage forms, the composition of active substances, method of application), 4) pharmacotherapeutic (ATC-classification, the mechanism of action) [5].

\section{Results and Discussion}

In order to standardize the provision of medical care, implementation of modern methods of diagnosis and treatment of brain injuries into the activities of medical preventive institutions, as well as the quality control of medical care, in 1998 the standards of medical care for victims of brain injury were developed, in 2004 the guidance "Modern principles of diagnosis and treatment of patients with urgent neurosurgical disorders (traumatic brain injury)" was writen, and in 2006 twelve protocols of rendering medical care in the specialty "Neurosurgery" were approved, in them the main directions of drug therapy of patients and pharmacological groups of drugs were determined [1,3,4]. However, when assessing the possibilities of practical use of protocols at the hospital level it has been found that they have no specific lists of drugs.

The rational selection of drugs to these lists can be made using the methods of pharmacoeconomic analysis; the first step is determining the basic pharmacological groups of drugs used to treat brain injuries, followed 


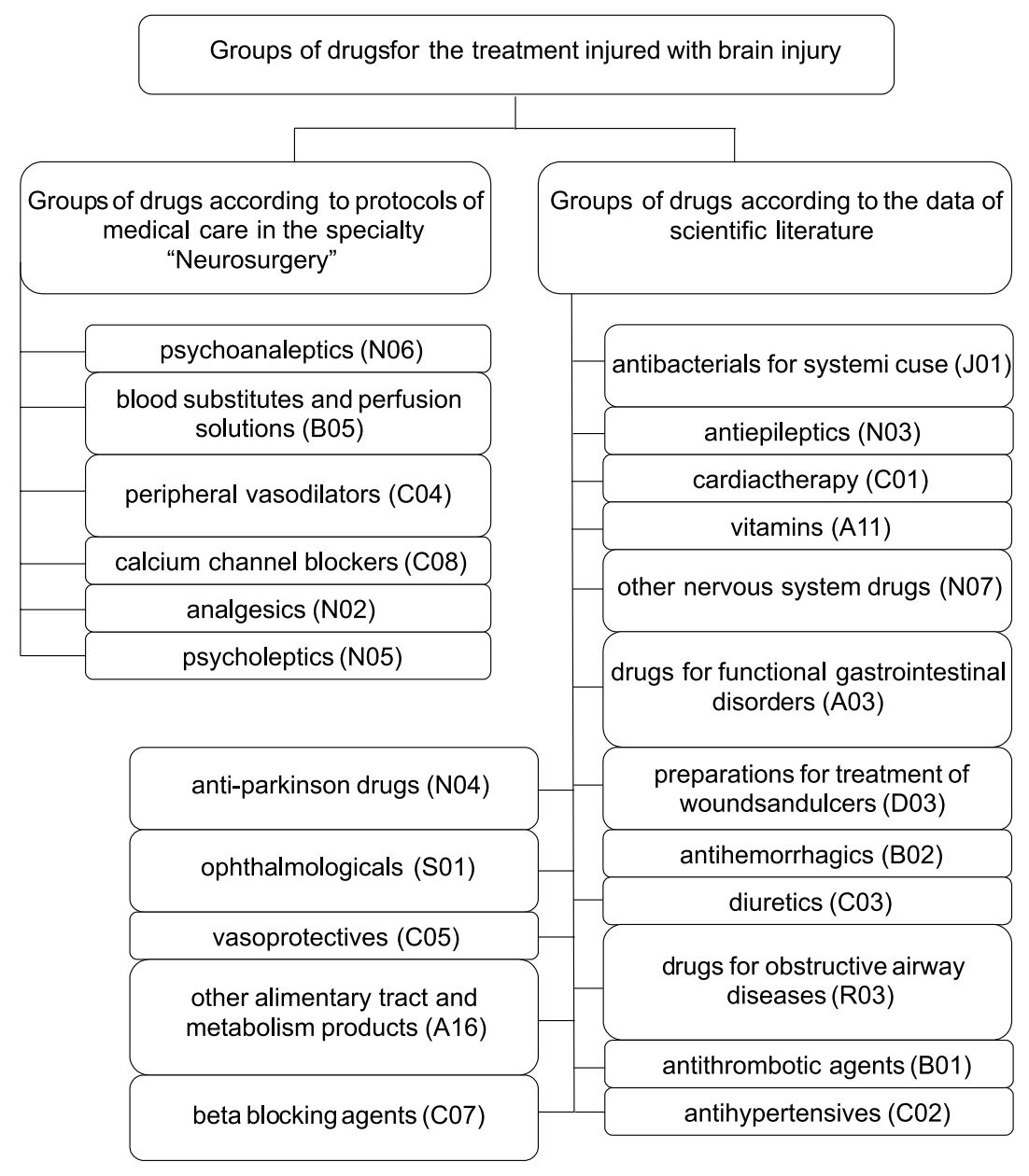

Fig. 1. The list of groups of drugs for treating injured people.

by carrying out marketing analysis of the given drugs. For this purpose the treatment protocols are analyzed, and the data of scientific literature and evidence-based medicine are systematized.

According to the protocols of medical care in the specialty "Neurosurgery" for treating patients with brain injuries the following groups of drugs are used. They are psychoanaleptics (N06), blood substitutes and perfusion solutions (B05), peripheral vasodilators (C04), calcium channel blockers (C08), analgesics (N02) and psycholeptics (N05); their use can provide only the minimum level of the necessary drug aid to the injured military men with brain injuries. They do not consider other group of drugs that are able to provide a higher level of care. Therefore, we decided to conduct the mar- keting analysis of all groups of drugs that could be used in the treatment of the traumatic brain injury $[2,8,10$, 11, 13, 15, 18, 19] (Fig. 1).

The analysis of the domestic pharmaceutical market as of 01/12/2013 showed that the aforementioned pharmacotherapeutical groups of drugs comprised 1034 drugs manufactured in 39 countries.

Ukraine produces 549 names of drugs, and it is almost $53 \%$ of the total range of medicines. The first place among the Ukrainian companies manufacturing drugs for treatment of the brain injury has "Darnitsa pharmaceutical company" JSC, the second one - "Yuria-Farm" Ltd., the third place Pharmaceutical company "Zdorovye" Ltd., the fourth one - "Kyivmedpreparat" PJSC, the fifth place - Scientific-Production Centre Borshchahivskiy Chemical-Pharmaceutical

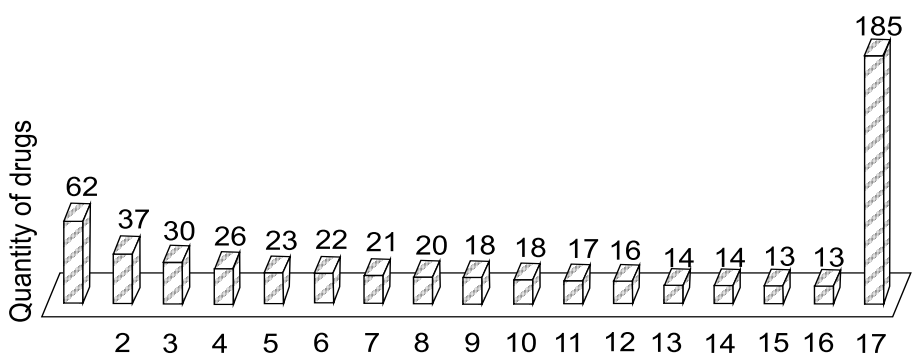

Fig. 2. The distribution of domestic production of drugs by manufacturers where: 1 - Darnitsya, 2 - Yuria-Farm, 3 - Zdorovie, 4 - Kyivmedpreparat, 5 - Borshchagivsky CPP, 6 - Biofarma, 7 - Niko, 8 - Galychfarm, 9 - Lekhim-Kharkiv, 10 - EP DNCLZ, 11 - Technolog, 12 - Farma-treid, 13 - Farmak, 14 - Infuzia, 15 - Kyiv Vitamin Factory, 16 - Lugansk Pharmaceutical ..., 17 - Other producers. 

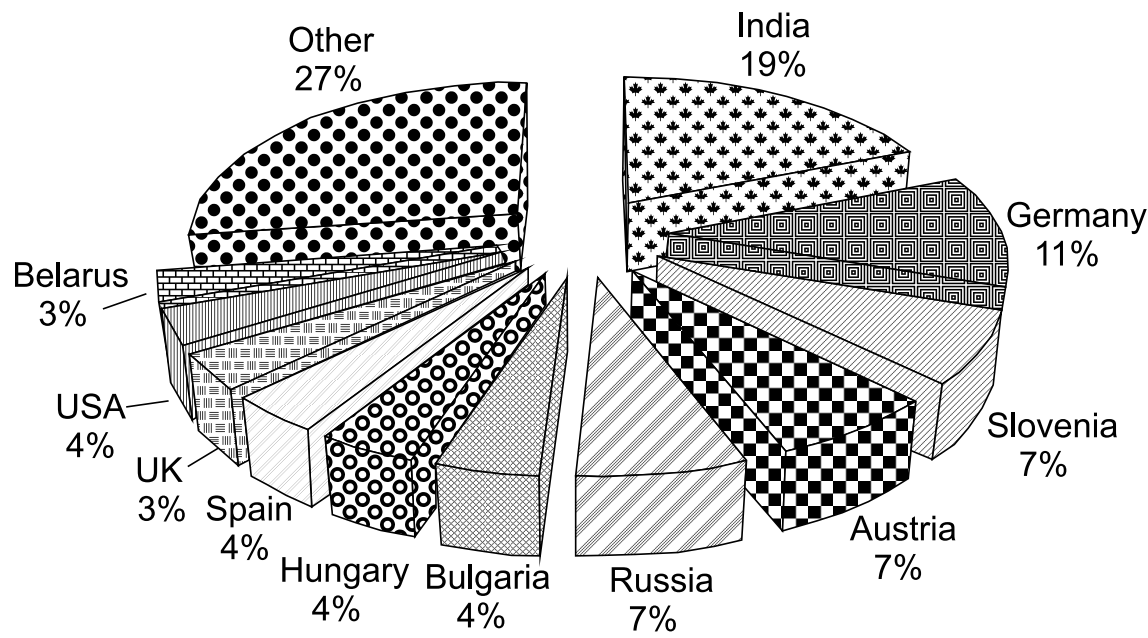

Fig. 3. The structure of the pharmaceutical market by producing countries.

Plant PLC, which supply 62, 37, 30, 26 and 23 medicines, respectively, and it is $17 \%$ of the total assortment (Fig. 2).

Foreign producers supply 485 drugs $(47 \%)$. The leader is India that provides the domestic market with 91 drugs, Germany and Slovenia take the second and third places in the import of drugs with 55 and 35 drugs, respectively (Fig. 3).

The largest importers are KRKA (Slovenia) - 22 drugs, Orchid (India) - 21, Ferrer International (Spain) - 17, Sopharma (Bulgaria) - 13, Gerot Pharmazeutica (Austria) - 12, Ranbaxy (India) - 11, AWD. Pharma (Germany) - 10, Sandoz Pharmaceuticals (Slovenia) - 10 .

Next we analyzed drugs by dosage forms (Table).

Approximately $49 \%$ of drugs are produced in the peroral forms, such as tablets, capsules, powders and solutions for oral use, syrups and pills. Dosage forms for injections are second $-48 \%$. These drugs include solutions for injections and infusions, powders and concentrates for preparation of injections and infusions. Almost 3\% of the total assortment are solutions for oral use, powders for preparation of suspensions, drops, etc.

Analyzing drugs according to the pharmacological groups it has been found that the largest assortment is represented by antibacterial agents for systemic use (J01) - 330 drugs, psychoanaleptics (N06) - 157, blood substitutes and perfusion solutions (B05) - 140, antiepileptics (N03) - 67, vitamins (A11) - 45, peripheral vasodilators $(\mathrm{C} 04)-42$, other drugs affecting the nervous system (N07) - 34, cardiac drugs (C01) - 32, drugs for functional gastrointestinal disorders (A03) - 30, calcium channel blockers (C08) - 29, analgesics (N02) - 27, antihemorrhagic drugs (B02) - 21, drugs for treating wounds and ulcers (D03) - 15, diuretics (C03) - 14, drugs used for obstructive airway diseases (R03) - 12,

Table

Distribution of drugs for treatment of the traumatic brain injury by dosage forms

\begin{tabular}{|c|c|c|c|c|c|c|c|c|}
\hline \multirow[b]{2}{*}{ Groups of drugs } & \multicolumn{8}{|c|}{ Quantity of drugs } \\
\hline & 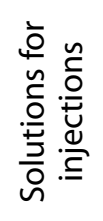 & 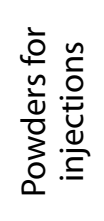 & $\frac{\frac{n}{0}}{\frac{0}{0}}$ & $\frac{\tilde{U}}{\frac{\tilde{U}}{\tilde{U}}}$ & 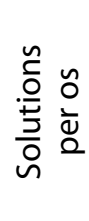 & 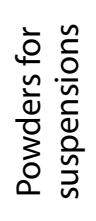 & 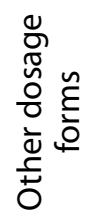 & $\begin{array}{l}\bar{\sigma} \\
\stackrel{\sigma}{0} \\
\end{array}$ \\
\hline Antibacterial agents for systemic use (J01) & 47 & 130 & 103 & 23 & & 10 & 17 & 330 \\
\hline Psychoanaleptics (N06) & 44 & 5 & 71 & 25 & 12 & & & 157 \\
\hline Blood substitutes and perfusion solutions (B05) & 140 & & & & & & & 140 \\
\hline Antiepileptics (N03) & 1 & & 60 & 3 & 3 & & & 67 \\
\hline Vitamins (A11) & 15 & 5 & 6 & 13 & 3 & & 3 & 45 \\
\hline Peripheral vasodilators (C04) & 12 & 2 & 26 & 2 & & & & 42 \\
\hline Other drugs affecting the nervous system (N07) & 12 & & 22 & & & & & 34 \\
\hline Cardiac drugs (C01) & 13 & 4 & 9 & 6 & & & & 32 \\
\hline Drugs for functional gastrointestinal disorders (A03) & 11 & & 18 & & & & 1 & 30 \\
\hline Calcium channel blockers (C08) & 5 & & 21 & 3 & & & & 29 \\
\hline Analgesics (N02) & 6 & & 17 & 4 & & & & 27 \\
\hline Other groups of drugs & 42 & 2 & 47 & 1 & & 3 & 6 & 101 \\
\hline All in all & 348 & 148 & 400 & 80 & 18 & 13 & 27 & 1034 \\
\hline
\end{tabular}




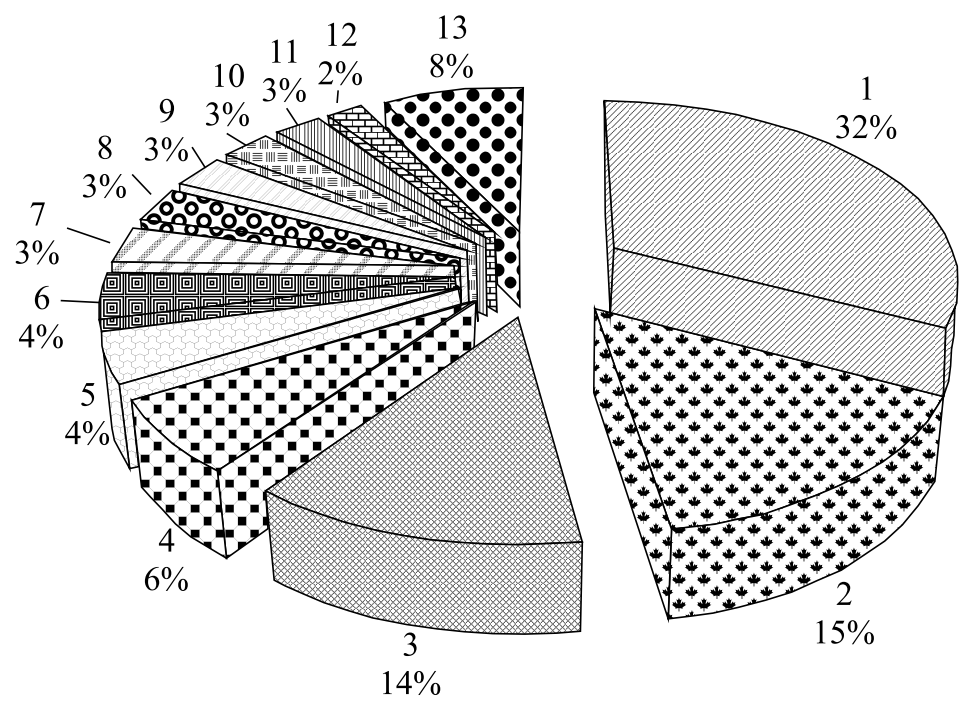

Fig. 4. The distribution of drugs by pharmacological groups where: 1 - antibacterial agents for systemic use, 2 - psychoanaleptics, 3 - blood substitutes and perfusion solutions, 4 - antiepileptics, 5 - vitamins, 6 - peripheral vasodilators, 7 - other drugs affecting the nervous system, 8 - cardiac drugs, 9 - drugs for functional gastrointestinal disorders, 10 - calcium channel blockers, 11 - analgesics, 12 - antihemorrhagic drugs, 13 - other groups.

antithrombotic agents (B01) - 12, antiparkinsonian drugs (N04) - 10, psycholeptics (N05) - 7, drugs used in ophthalmology (S01) - 3, vasoprotectives (C05) - 2, other drugs affecting digestive system and metabolism (A16) -2 , beta adrenoreceptor antagonists $(\mathrm{C} 07)-2$, antihypertensives (C02) - 1 (Fig. 4).

\section{CONCLUSIONS}

As a result of market research, we can conclude that the Ukrainian firms produce a sufficient number of medicines: 60 producers supply 549 types of drugs to the domestic pharmaceutical market, and it is sufficient to meet the needs of the affected military men with brain injuries in drugs.

\section{REFERENCES}

1. База стандартів медичної допомоги в Украйні. [Електронний ресурс]. - Режим доступу: http://www. moz.gov.ua/ua/portal/register_standardsof medicalaid.

2. Белозериев Ю.А., Запольская Ю.А., Белозериев Ф.Ю., Юнцев С.В. //Эксперим. и клин. фармакол. - 2012. №12. - C. 11-14.

3. Бриф-анализ фармрынка: итоги августа 2013 г. [Электронный ресурс]. - Режим доступа: http://www. apteka.ua/article/251331.

4. Государственный реестр лекарственных средств Украины [Электронный ресурс]. - Режим доступа: http://www.drlz.kiev.ua.

5. Дремова Н.Б. // Курский науч.-практ. вестник «Человек и его здоровье». - 2005. - №1. - С. 62-76.

6. Лихтерман Л.Б. Нейротравматология. - Ростов н/Д: Изд-во «Феникс». Изд. 2-е, 2008. - 576 с.

7. Островая Т.В., Черний В.И., Андронова И.А. // Междунар. неврол. журн. - 2007. - №2. - С. 2-11.

8. Педаченко Е.Г., Дзяк Л.А., Сирко А.Г. // Журн. Вопросы нейрохирургии им. Н.Н.Бурденко. - 2012. - №5. C. 30-39.

9. Черний В.И., Островая Т.В., Андронова И.А. // Медицина неотложных состояний. - 2008. - №2(15). C. 99-106.

10. Adibhatla R.M., Hatcher J.F. // Neurochem. Res. - 2005. - Vol. 30, №1. - P. 15-23.

11. Adibhatla R.M., Hatcher J.F., Dempsey R.J. // J. Neurochem. - 2002. - Vol. 80. - P. 12-23.

12. Bullock R., Chestnut R., Chajar J. // Neurotrauma. -2007. - Vol. 24, suppl. 1. - 106 p.

13. Davalos A., Castillo J., Alvarez-Sabin J. et al. // Stroke. - 2002. - Vol. 33. - P. 2850-2857.

14. Faden A.I. // Arch. Neurol. - 2001. - Vol. 58. - P. 1553-1555.

15. Maas A.I. // Expert Opin. Investig. Drugs. - 2001. - Vol. 10. - P. 753-767.

16. Reilly P.L., Bullock R. (eds). Head injury, pathophysiology and management. - 2-nd ed. -2005. - 501 p.

17. Rogalewski A., Schneider A., Ringelstein E.R., Schabitz W.-R. // Stroke. - 2006. - Vol. 37. - P. 1129-1136.

18. Stoccetti N., Zanaboni C., Colombo A., Beretta G. // Intensive Care Medicine. - 2008. - Vol. 34 - P. 1-5.

19. Zweiflern R.M. // Current Med. Res. and Opinions. - 2002. - Vol. 18, suppl. 2. - P. 14-17. 


\section{МАРКЕТИНГОВИЙ АНАЛІЗ ПРЕПАРАТІВ, ЯКІ ВИКОРИСТОВУЮТЬСЯ ДЛЯ ЛІКУВАННЯ ПОТЕРПІЛИХ ВІЙСЬКОВОСЛУЖБОВЦІВ ІЗ ТРАВМАМИ ГОЛОВНОГО МОЗКУ О.П.Шматенко, А.М.Соломенний, О.В.Плєшкова \\ Ключові слова: маркетинговий аналіз; травма головного мозку; медикаментозне} лікування; лікарські засоби

У ході дослідження проведено порівняльний аналіз протоколів надання медичної допомоги хворим із травмами головного мозку та відомостей наукової літератури і доказової медицини. Він свідчить, що для лікування постраждалих військовослужбовців із травмами головного мозку використовуються такі групи лікарських засобів, як антибактеріальні засоби для системного використання, психоаналептики, кровозамінники та перфузійні розчини, протиепілептичні засоби, вітаміни, перифреричні вазодилататори, кардіологічні препарати, антагоністи кальцію, аналгетики, антигеморагічні засоби, засоби для лікування ран та виразкових уражень, сечогінні засоби, антитромботичні засоби, протипаркінсонічні препарати, психолептичні засоби, ангіопротектори, блокатори $\beta$-адренорецепторів тощо. Маркетинговий аналіз визначених груп лікарських засобів проводився за наступними показниками: правовий (реєстрація в Україні), економічний (виробничий: країна, фрірма), фрармацевтичний (види лікарських форм, склад діючих речовин, спосіб застосування); фрармакотерапевтичний (АTCкласифрікація). Аналіз вітчизняного фрармацевтичного ринку показав, що лікарські засоби для лікування травм голови нараховують 1034 препаратів, які виробляються в 39 країнах світу. Було встановлено, що українські виробники здатні забезпечити необхідний рівень надання медикаментозної допомоги при лікуванні черепно-мозкової травми і виробляють 549 найменувань препаратів, що складає майже 53\% від загального асортименту медикаментів. Перше місце серед українських фрірм з виробництва лікарських засобів для лікування травм головного мозку посідає ПрАТ «Фармацевтична фрірма «Дарниця», друге - ТОВ «Юрія-Фарм», третє - ТОВ «Фармацевтична компанія «Здоров'я». Іноземні виробники постачають 485 препаратів (47\%). Лідерами є Індія, Німеччина та Словенія, які посідають перше, друге і третє місця в імпорті лікарських засобів відповідно.

\section{МАРКЕТИНГОВЫЙ АНАЛИЗ ПРЕПАРАТОВ, КОТОРЫЕ ИСПОЛЬЗУЮТСЯ ДЛЯ ЛЕЧЕНИЯ ПОСТРАДАВШИХ ВОЕННОСЛУЖАЩИХ С ТРАВМАМИ ГОЛОВНОГО МОЗГА}

А.П.Шматенко, А.Н.Соломенный, О.В.Плешкова

Ключевые слова: маркетинговый анализ; травма головного мозга; медикаментозное лечение; лекарственные средства

В ходе исследования проведен сравнительный анализ протоколов оказания медицинской помощи больным с травмами головного мозга и сведений научной литературы и доказательной медицины. Он показал, что для лечения пострадавших военнослужащих с травмами головного мозга используются такие группы лекарственных средств, как антибактериальные средства для системного использования, психоаналептики, кровезаменители и перфузионные растворы, противоэпилептические средства, витамины, периферические вазодилататоры, кардиологические препараты, антагонисты кальция, анальгетики, антигеморрагические средства, средства для лечения ран и язвенных поражений, мочегонные средства, антитромботические средства, противопаркинсонические препараты, психолептические средства, ангиопротекторы, блокаторы $\beta$-адренорецепторов и т.д. Маркетинговый анализ определенных групп лекарственных средств проводился по следующим показателям: правовой (регистрация в Украине), экономический (производственный: страна, фрирма), фрармацевтический (виды лекарственных фрорм, состав действующих веществ, способ применения); фрармакотерапевтический (АТС-классификация). Анализ отечественного фрармацевтического рынка показал, что лекарственные средства для лечения травм головы насчитывают 1034 препаратов, которые производятся в 39 странах мира. Было установлено, что украинские производители способны обеспечить необходимый уровень оказания медикаментозной помощи при лечении черепно-мозговой травмы и производят 549 наименований препаратов, что составляет почти 53\% от общего ассортимента лекарственных средств. Первое место среди украинских фирм по производству препаратов для лечения травм головного мозга занимает ЧАО «Фармацевтическая фрирма «Дарница», второе - ООО «ЮрияФарм», третье - ООО «Фармацевтическая компания «Здоровье». Иностранные производители поставляют 485 препаратов (47\%). Лидерами являются Индия, Германия и Словения, которые занимают первое, второе и третье места в импорте лекарственных средств соответственно. 